\title{
Degree Of Internationalization - A Multidimensional Challenge
}

Lutz Sommer, Albstadt-Sigmaringen University, Germany

\begin{abstract}
Studies dealing with the internationality of executive boards of large enterprises show that their internationality - as measured by share of foreign sales - differs significantly from the internationality of the enterprise activities. This was confirmed by the present survey on mediumsized enterprises from Singapore. Furthermore, it could be noticed that on the one hand that in order to explain exeutive board internationality, the internationality indicator , International work experience of the executive board members" has a high importance compared to the three other indicators examined, i.e. multinationality expressed as the board members' nationality, international education, and international relations. On the other hand this indicator is the only one that has a measurable influence on the internationality of the enterprise activities - the latter being measured by the company's share of foreign sales. This lets indicator "multi-nationality" that is frequently used in literature as a key-indicator of the internationality of an executive board appear to be overrated compared to other indicators generally used in studies on internationality. Thus, future studies in the field should consider its rather limited explanatory value.
\end{abstract}

Keywords: Internationalization, SME, Degree of internationalization

Analysis of the influence of internationality of the executive board of medium-sized enterprises on the internationality of the enterprise activities in general and on the internationality of small and medium-sized enterprises in Singapore in particular.

\section{INTRODUCTION}

C nternationalization becomes more and more important for small and medium-sized enterprises (SME) in Germany. The renowned German "Mittelstandsbarometer 2007" (SME barometer) shows that international markets increasing in complexity create a competitive stress forcing the SME to become more active in foreign markets (Mittelstandsbarometer 2007, pp. 93 et seqq.). This is shown more clearly in the export rate of export SME, which rose from 17\% to 20\% (Mittelstandsbarometer 2007, pp. 99 et seqq.). On top of that, a current study by Deloitte and the International University Reichartshausen (EBS) / Germany on globalization of medium-sized enterprises documents an increasing growth of activities abroad (Hommel / Brockmann 2007, pp. 5 et seqq.). There is hardly any study from well known institutes that doubts this trend.

This development is not only observable in Germany, but also in many parts of Europe, as the results of the monitoring network of the EU 2007 confirm (Flash Eurobarometer 196 / 2007, pp. 6 et seqq.). It is particularly noticeable, that in small economies the foreign commitment of SMEs is higher and that obviously the probability for foreign sales increases as SMEs expand. We note that the exports of SMEs increased by an average of $12 \%$ in 2006 compared to 2005 (Flash Eurobarometer 196 / 2007, pp. 17 et seqq.). The medium-sized enterprises in the USA and Asia are as well captured by globalization. Amongst others, Singapore's medium-sized enterprises have wide experience with globalization. An analysis of the top 500 medium-sized enterprises in Singapore shows, that the effect of globalization on medium-sized enterprises was obviously positive, because in 2004 and 2005 the turnover gains were $6.97 \%$ and $12.58 \%$, respectively. These values lie above the average economic growth of Singapore (DP Information Group 2007). These results lead to the question why SMEs are so successful in Singapore. Are their executive boards characterized by a disproportionately high internationality and thus profit by the global environment? 
To answer this question, we need to clarify in advance, what characterizes an internationally operating enterprise. Because of the diversity of definitions for an international enterprise, from quantitative definitions " $\mathrm{A}$ multinational has more than 50 percent of operation overseas" (Bruck/ Lees 1966) to qualitative transcriptions by Claver/Quer: “...multinational generally describes ... interests outside its country of origin” (Claver/Quer 2001, p.17), Fischer analyzed 37 different definitions and concluded that concerning terminology there is no clear definition for the internationality of an enterprise (Fischer, 2006).

However, there are certain attributes that are mentioned regularly for the characterization of international enterprises. These include amongst others attributes like foreign market cultivation, balance sheet values, geographical diversification and foreign orientation of the management (Fischer 2006, pp. 35 et seqq.): (a) To systemize the definitions as regards content Aharoni suggests three categories, structural criterion, performance and behavioural characteristics; (b) The category "behavioural characteristics" measures the internationality e.g. based on the international work experience of the executive board; The category "structure" measures the internationality e.g. on the basis of branches abroad, number of countries involved or the ownership and the category "performance" measures internationality on the basis of certain characteristics, e.g. sales, profit or assets (Aharoni 1971); (c) This systematization was further developed, special attention should be paid to the increased use of the term 'dimensions' instead of 'categories' since the 1990's (Fischer, 2006).

Concluding it can be said that for the survey of the internationality of an enterprise or its activities different dimensions are necessary. This means that presumably there are at least three dimensions or categories which allow us to speak of a "multi-dimensionality of internationality" (Fischer 2006, p. 41). The present study focuses on the interdependencies between the individual dimensions. Here it shall be explored to what extent the dimension "behaviour" for example correlates with the dimensions "structure and performance" (= existing structure/ performance). On the assumption that a progressive internationalisation of enterprise activities is regarded as beneficial for SMEs, too, the question arises, which actor in such SMEs represents best the dimension "behaviour".

Undoubtedly, the biggest influential power on SME activities lies mostly in the hands of the enterprise management (Sommer / Durst / Haug 2007, pp. 256 et seqq.). Its role in the internationalization process is already extensively examined. EU Commission discovered in the aforementioned report that the most common problems in SME internationalization are the lack of a clear strategy, absence of know-how on internationalization activities, information asymmetries when seeking suitable partners and misjudgements on the market potential (Observatory of European SMEs 2003, pp. 35 et seqq.). Other aspects are the experiences of managers regarding internationalization. Different studies mentioned the relevance of the managers' attitudes (CEDEFOP 2002; Ajzen/ Fishbein 1980; Ajzen/ Madden 1986; Allport 1935; Rosenberg/ Hovland 1960). These issues are summarized as follows (Observatory of European SMEs 2003, p. 37):

“... are the personal characters such as mentality and individual preferences of the small enterprise owner, as well as their dedication and purposefulness the key drivers for the success in overseas."

\section{STATE-OF-THE-ART OF RESEARCH AND SCIENTIFIC OBJECTIVES}

Aharoni's concept has been further developed or supplemented by different authors (Berghe 2003). The majority of these authors assume a multi-dimensionality of internationality (Fischer 2006, pp. 44 et seqq.). However, in order to reach the scientific objective of this study we need to measure the three dimensions specified above which is quite a scientific challenge. Therefore, we will start with a close examination of the state-of-the-art of research on this matter. Subsequently, we will define the scientific approach with regard to interdependencies between the dimensions and then formulate the research hypotheses.

\subsection{Measuring of the internationality of the enterprise}

As already described there are different dimensions of internationality, based on Aharoni (1971), and further developed by Perridon/ Rössler (1980), Raghunathan/ Chandran (1990) or Berghe (2003). Dörrenbächer describes the above dimensions in the form of indicators at which per dimension a variety of indicators can exist (Dörrenbächer 2000, p. 4). However, the number of possible indicators is even larger. Germann/ Rürup/ Setzer have identified 47 indicators (Germann et al. 1996). 
Table 1: Internationalization Indicators

\begin{tabular}{|c|c|c|}
\hline Structural Indicators & Performance Indicators & Attitudinal Indicators \\
\hline $\begin{array}{l}\text { 1. Relating to foreign activities } \\
\text { Number of countries an enterprise } \\
\text { is active in } \\
\text { Number or proportion of foreign } \\
\text { affiliates } \\
\text { Number or proportion of non- } \\
\text { capital involvements abroad (e.g. } \\
\text { strategic alliances, franchised } \\
\text { operations) } \\
\text { Amount or proportion of foreign } \\
\text { assets } \\
\text { Amount or proportions of value } \\
\text { added abroad } \\
\text { Amount or proportion of sourcing } \\
\text { abroad } \\
\text { Number or proportion of foreign } \\
\text { employees } \\
\text { 2. Relating to governance structures } \\
\text { Number of stock markets on which a } \\
\text { enterprise is listed } \\
\text { Amount or proportion of shares } \\
\text { owned by foreigners } \\
\text { Number or proportion of non- } \\
\text { nationals in the board of directors }\end{array}$ & $\begin{array}{l}\text { 1. Foreign Sales } \\
\text { Demand: Amount of foreign sales } \\
\text { by customer location } \\
\text { Exports from the home country } \\
\text { +Revenues of foreign affiliates } \\
\text { - their revenues from exports to the } \\
\text { home country } \\
\begin{array}{l}\text { Supply: Amount of sales of } \\
\text { foreign affiliates }\end{array} \\
\text { Sum of revenues of foreign } \\
\text { affiliates } \\
\text { 2. Operating income abroad } \\
\text { Sum of operating income of } \\
\text { foreign affiliates }\end{array}$ & $\begin{array}{l}\text { 1. 'Soft' indicators } \\
\begin{array}{l}\text { Ethno-, poly-, region- or geocentric } \\
\text { management style according to: } \\
\text { organisational complexity, } \\
\text { authority, decision making, } \\
\text { communication flows, } \\
\text { recruiting, staffing, } \\
\text { control }\end{array} \\
\text { 2. 'Hard' indicators } \\
\text { International experience of top } \\
\text { managers } \\
\text { Cumulative duration of the years } \\
\text { top managers spent working } \\
\text { abroad } \\
\text { weighted by the total years of } \\
\text { their working experience }\end{array}$ \\
\hline
\end{tabular}

Source: Adapted from Dörrenbächer 2000

In order to measure internationality we could examine individual indicators or group several indicators into suitable categories. There are several possible ways of grouping indicators. In the remainder of this section, three important approaches will be discussed in detail based on the work of Fischer (Fischer, 2006):

(a) The first possibility is typology. We talk about typology if indicators are combined differently without concentrating the combinations into new categories. The objective is to describe the differences between enterprises. As an example we would like to refer to the typology of Bartlett and Ghoshal (Bartlett / Ghoshal 1989, pp. 16 et seqq.). Based on case studies in different enterprises, the authors describe four types of strategies, namely the international, the multinational, the global and the transnational enterprise. Another typology approach goes back to Perlmutter who points out the attitude of the management as a dimension. It assumes that the internationality of an enterprise is not only measurable by quantifiable indicators like foreign sales but is expressed by the attitude of the management towards the international business. The result is the so-called EPRG-Model according to which every enterprise has its own EPRG profile (Perlmutter 1969, pp. 11 et seqq.). Hence attitudes and behaviour can be regarded as promoting factors for the development of international structures and strategies of an enterprise (Schmid 1996, pp. 32 et seqq.). Other relevant typologies suggest to abandon the view of the corporate level (Cheng/ Ramaswamy 1989, pp. 105 et seqq.) or to focus on the networking character of an international enterprise (Johanson/ Gunnar-Mattsson 1986, pp. 240 et seqq.). As Fischer put it, characteristics or attributes, respectively, regularly discussed in literature can be subsumed under one of the following six dimensions (Fischer 2006, pp. 83 et seqq.):

Table 2: Dimensions of the internationality of enterprises

\begin{tabular}{|l|l|}
\hline \multicolumn{1}{|c|}{ Dimension } & \multicolumn{1}{c|}{ Description } \\
\hline Structure & Structure of the Organization \\
\hline Performance & Profit, Sales, Investments \\
\hline Behaviour & Attitude of the management \\
\hline Environment & Branch environment/Historical environment \\
\hline Strategy & Local differentiation/global Standardisation \\
\hline Resources & Resource allocation / technological skills \\
\hline
\end{tabular}

Source: Own illustration based on Fischer 2006, p. 83 
(b) The illustrated typologies by themselves do not give a comprehensive view of the internationality of enterprises because the quantitative part is often not sufficiently integrated. The second possibility consists in the creation of indices as a quantitative form of assessing the internationality of enterprises. An index combines several indicators and merges them in categories in order to obtain a data reduction. In this context we talk of multiple item concepts. They reach from the combination of the ratio of foreign capital to total assets with foreign employees (Hughes / Logue / Sweeney 1975, pp. 630 et seqq.) to the average information content according to Heinrich (Heinrich 2003). These quantitative recording concepts can in turn contain the dimensions already discussed in the context of the typology (Berghe 2003, p. 312). In the literature the following three indices are applied frequently and shall therefore be closer examined (Dörrenbächer, 2000):

- $\quad$ TRANSNATIONALITY INDEX (TNI): This index appeared in the World Investment Report 1995 (UNCTAD 1995). The aim of the index is to "... capture fully the extent of involvement of TNCs [transnational companies] in the world economy" (UNCTAD 1995, p. 24). The index is based on three different ratios: Foreign sales to total sales, foreign assets to total assets, and foreign employment to total employment.

- TRANSNATIONAL ACTIVITY SPREAD INDEX (TASI): This index, published by Ietto-Gillies (Ietto-Gillies 1998, pp. 16 et seqq.), combines two indices. Ietto-Gillies illustrated that the above mentioned index by UNCTAD ignores the spread of foreign activities. She suggested complementing the UNCTAD index by the "network spread index". The outcome is a new concept, which is called "Transnational Activity Spread Index".

- DEGREE OF INTERNATIONALIZATION (DOI): The last index was published by Sullivan (Sullivan 1994, p. 165, Sullivan 1996, pp. 180 et seqq.). He used five indicators: The ratios of foreign sales to total sales, foreign assets to total assets, and number of foreign subsidiaries to total number of subsidiaries, the international experience of top managers/ boards and the psychic dispersion of international operations. The following table gives an overview of how these indices are composed:

Table 3: Indices to measure internationalization

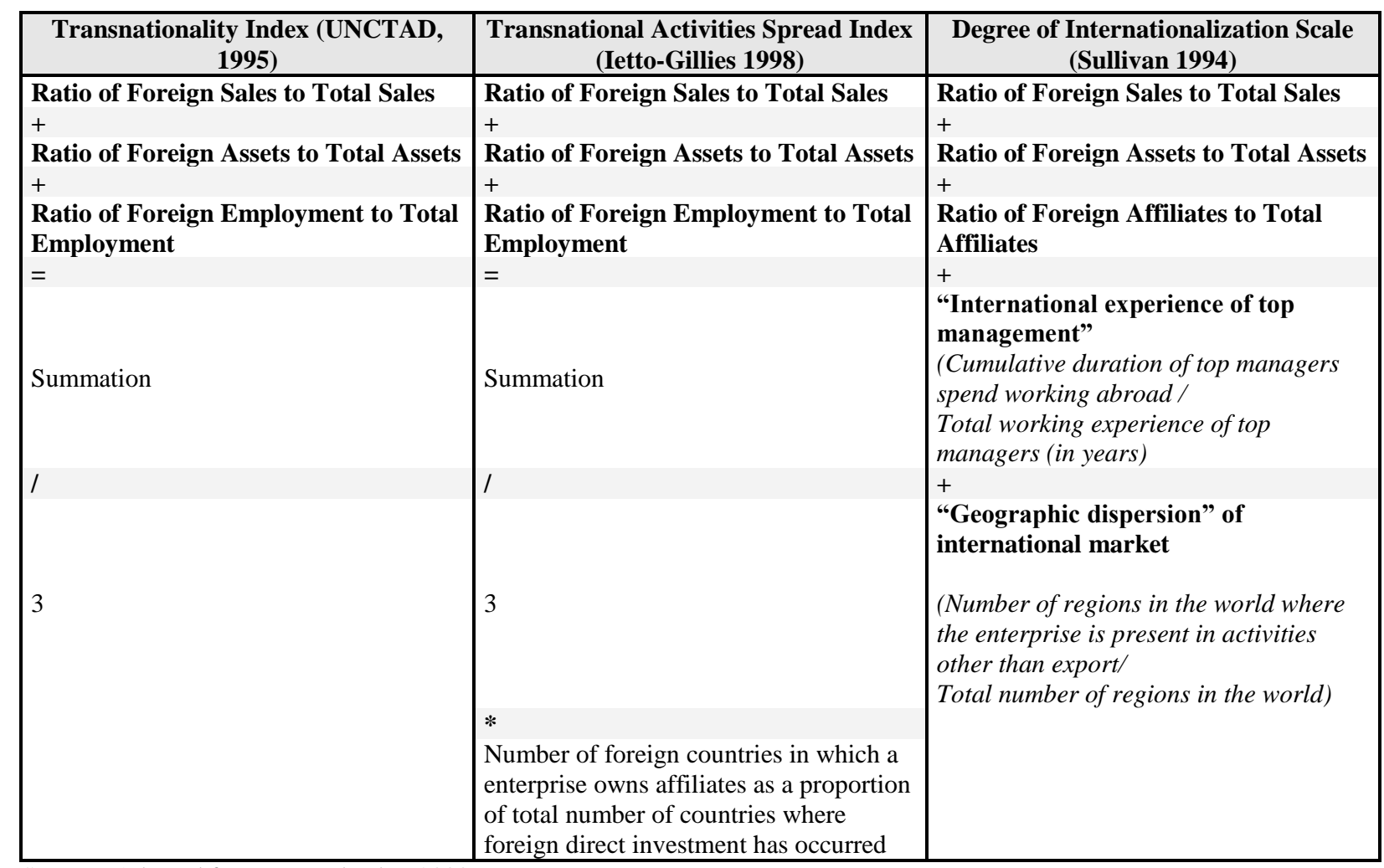

Source: Adapted from Dörrenbächer 2000 
For the analysis of the interdependences between the structure and performance dimension and the behaviour dimension the TNI and the TASI can be used. The DOI is dropped since it already contains at least partly the behaviour dimension via the international experience of the top management. In conclusion it can be said that with multiple measure concepts special attention has to be paid to the manageability on the one hand and to minimizing the loss of information with regard to the grouping of indicators on the other hand (Fischer 2006, pp. 174 et seqq.).

(c) The third possibility of grouping indicators consists in forming internationalization profiles. Hederer and colleagues have created a profile in which they compare two enterprises with each other (Hederer et al. 1970, pp. 517 et seqq.); Kutschker and Schmid illustrate the internationality of enterprises in form of threedimensional mountains (Kutschker/Schmid 2006, pp. 325 et seqq.). Another interesting approach is the one of Hassel/ Höpner/ Kurdelbusch/ Rehder/ Zugehör who have developed a two-dimensional concept which as well shows a profile character (Hassel et al. 2003, pp. 705 et seqq.). These concepts to measure internationality have been presented for illustrational purposes foremost, thus only a limited number of approaches has been selected.

2.2. Survey on interdependences between the behavioural dimension and the performance and structure dimension of the internationality of enterprises

As already illustrated the development of measure concepts on the basis of the different dimensions of the internationality of enterprises makes up a large part in the literature. The interdependences between the dimensions in general and between the behavioural dimension and the performance and structure dimensions in particular are discussed only to a limited extent in current literature.

For the current survey four studies shall be consulted which set the behavioural dimension - that is the internationality of the executive board - in relation with the performance or structure dimension - that is the internationality of the enterprise activities. The first two studies refer to German enterprises, the third study refers to enterprises from Denmark and Sweden which within Europe strongly operate on the global market and the last study refers to the 150 largest transnational enterprises worldwide - short TNC - according to the World Trade and Development Conference of the United Nations (UNCTAD).

In the first study the business consultancy Simon Kucher \& Partner examined the enterprises listed at the German stock index DAX on the basis of their business reports with regard to their internationality in 2005 (Lesch 2005 , p. 2). For this purpose five internationalization indicators as defined by the Max Planck Institute for the Study of Societies (MPIfG) were used. These included foreign sales, number of persons employed abroad, spread of the overseas branches/ subsidiaries, owner structure and international experience of the executive board (Max-PlanckInstitut für Gesellschaftsforschung 2002, pp. 18 et seqq.). The results of the grouping of the first four indicators in the performance and structure dimension can be summed up as follows (Lesch 2005, pp. 3 et seqq.):

Table 4: Results of the Lesch study (2005)

\begin{tabular}{|c|c|c|}
\hline Indicators: Performance or structure dimension & Result of 1998 & Result of 2004 \\
\hline Foreign sales compared to the total turnover & $59,5 \%$ & $68,1 \%$ \\
\hline
\end{tabular}

Table 5: Results of the Lesch study (2005)

\begin{tabular}{|l|c|c|}
\hline \multicolumn{1}{|c|}{ Indicators: behavioural dimension } & result of 2000 & result of 2005 \\
\hline Foreign quota in executive boards & $14,3 \%$ & $20,4 \%$ \\
\hline Foreign experience more than one year & No Information & $63,0 \%$ \\
\hline
\end{tabular}

Source: Own illustration

The descriptive data show that there is a discrepancy between the foreign sales (68.1\% in 2004) and the number of foreign executive board members (20.4\% in 2005). However, in the author's opinion the international work experience $(63 \%)$ which is almost as high as the foreign sales makes up for that. The following table shall specify the facts for the year 2004 again (Lesch 2005, pp. 13 et seqq.): 
Table 6

Results of the Lesch Study (2005); AU = share of foreign sales in the total turnover, $\mathrm{AE}=$ share of executive members with international work experience / education in the total number of the executive board members

\begin{tabular}{|l|c|c|l|c|c|}
\hline \multicolumn{1}{|c|}{ Enterprise } & AU & AE & \multicolumn{1}{c|}{ Enterprise } & AU & AE \\
\hline 1.Henkel & $83,0 \%$ & $100 \%$ & 15. Deutsche Post & $47,7 \%$ & $63,0 \%$ \\
\hline 2. Siemens & $77,3 \%$ & $83,0 \%$ & 16. Münchner Rück & $54,0 \%$ & - \\
\hline 3. Schering & $89,1 \%$ & $71,0 \%$ & 17. Linde & $78,6 \%$ & $75,0 \%$ \\
\hline 4. DaimlerChrysler & $84,3 \%$ & $70,0 \%$ & 18. BMW & $73,0 \%$ & $67,0 \%$ \\
\hline 5. Deutsche Bank & $69,4 \%$ & $50,0 \%$ & 19. SAP & $76,3 \%$ & $43,0 \%$ \\
\hline 6. Commerzbank & - & $71,0 \%$ & 20. MAN & $73,5 \%$ & $29,0 \%$ \\
\hline 7. Allianz & $68,0 \%$ & $80,0 \%$ & 21. Volkswagen & $72,5 \%$ & $50,0 \%$ \\
\hline 8. Thyssen-Krupp & $65,5 \%$ & $43,0 \%$ & 22. E. ON & $39,4 \%$ & $50,0 \%$ \\
\hline 9. RWE & $45,2 \%$ & $50,0 \%$ & 23. Altana & $82,4 \%$ & $50,0 \%$ \\
\hline 10. Infineon & $76,7 \%$ & $100 \%$ & 24. TUI & $90,6 \%$ & $25,0 \%$ \\
\hline 11. BASF & $80,3 \%$ & $100 \%$ & 25. Bayer & - & $75,0 \%$ \\
\hline 12. Adidas-Salomon & - & $50,0 \%$ & 26. Metro & $49,0 \%$ & $25,0 \%$ \\
\hline 13. Lufthansa & - & $67,0 \%$ & 27. Deutsche Telekom & $39,3 \%$ & $40,0 \%$ \\
\hline 14. Continental & $67,0 \%$ & $60,0 \%$ & average & $\mathbf{6 8 , 1} \%$ & $\mathbf{6 3 , 0} \%$ \\
\hline
\end{tabular}

Source: Own illustration

The second study was conducted by the European School of Management Berlin in 2007. Data source were annual reports and interviews with about 500 persons from executive boards and boards of directors of DAXlisted enterprises.

Data on foreign sales, on the number of employees working abroad and on the internationality of the executive board members were collected as indicators in the form of an index. This index - called the internationality index - is used to measure the behavioural dimension (= international orientation of the executive board/ board of directors ) and is composed of the multi-nationality of its members, the internationality of their education, their international work experience and international mandates, as the following table illustrates (Schmid 2007, p. 4):

$$
\text { Index INT } T_{\log }=\frac{1}{n} \times \sum_{i=1}^{n}\left(\frac{1}{4}\left(F_{i}+\left(1-\frac{1}{E_{i f}+1}\right)+\left(1-\frac{1}{W_{i f}+1}\right)+\left(1-\frac{1}{A_{i f}+1}\right)\right)\right)
$$

n -- Total number of the executive board or supervisory board members

$F_{i} \quad--$ Nationality of person $i ; F=0$ for Germany; $F=1$ for foreign countries

$E_{i f}--$ Number of training years of person i spent abroad in country $f$

$\mathrm{W}_{\text {if }}$-- Number of working years of person i spent abroad in country $\mathrm{f}$

$\mathrm{A}_{\mathrm{if}} \quad-$ - Number of mandates person $\mathrm{i}$ has at enterprises abroad in country $\mathrm{f}$

The descriptive results are illustrated as follows for the year 2006 (Schmid 2007, pp. 17 et seqq.):

Table 7

Results of the Schmid study (2007); $\mathrm{AU}$ = share of foreign sales in the total turnover, $\mathrm{AM}=$ share of foreign employees in the total number of employees; Index = Internationality index

\begin{tabular}{|l|c|c|c|l|c|c|c|}
\hline \multicolumn{1}{|c|}{ Enterprise } & AU & AM & Index & \multicolumn{1}{|c|}{ Enterprise } & AU & AM & Index \\
\hline 1.Henkel & - & $78,9 \%$ & $37,4 \%$ & 15. Deutsche Post & $49,7 \%$ & $66,1 \%$ & $16,5 \%$ \\
\hline 2. Siemens & $79,2 \%$ & $64,1 \%$ & $38,9 \%$ & 16. Münchener Rück & $54,5 \%$ & $28,7 \%$ & $28,0 \%$ \\
\hline 3. Schering & $89,9 \%$ & $63,8 \%$ & $34,1 \%$ & 17. Linde & $79,8 \%$ & $65,0 \%$ & $24,5 \%$ \\
\hline 4. DaimlerChrysler & $86,0 \%$ & $52,2 \%$ & $43,2 \%$ & 18. BMW & $76,4 \%$ & $24,4 \%$ & $30,2 \%$ \\
\hline 5. Deutsche Bank & - & $58,5 \%$ & $20,4 \%$ & 19. SAP & $78,7 \%$ & $61,2 \%$ & $18,5 \%$ \\
\hline 6. Commerzbank & - & $23,5 \%$ & $32,0 \%$ & 20. MAN & $74,3 \%$ & $37,4 \%$ & $26,9 \%$ \\
\hline 7. Allianz & $68,0 \%$ & $59,4 \%$ & $27,2 \%$ & 21. Volkswagen & $72,4 \%$ & $48,2 \%$ & $20,1 \%$ \\
\hline 8. Thyssen-Krupp & $66,0 \%$ & $53,1 \%$ & $28,4 \%$ & 22. E.ON & $40,5 \%$ & $57,3 \%$ & $15,1 \%$ \\
\hline 9. RWE & $44,9 \%$ & $49,3 \%$ & $23,0 \%$ & 23. Altana & $82,2 \%$ & $52,2 \%$ & $16,1 \%$ \\
\hline 10. Infineon & $80,0 \%$ & $55,8 \%$ & $28,9 \%$ & 24. TUI & $70,8 \%$ & $75,0 \%$ & $33,0 \%$ \\
\hline 11. BASF & $79,3 \%$ & $43,6 \%$ & $24,6 \%$ & 25. Bayer & $84,8 \%$ & $59,9 \%$ & $23,0 \%$ \\
\hline 12. Adidas-Salomon & - & $82,0 \%$ & $24,8 \%$ & 26. Metro & $53,4 \%$ & $50,4 \%$ & $19,6 \%$ \\
\hline 13. Lufthansa & - & $33,9 \%$ & $25,4 \%$ & 27. Deutsche Telekom & $42,6 \%$ & $31,1 \%$ & $14,5 \%$ \\
\hline 14. Continental & $66,0 \%$ & $61,2 \%$ & $31,4 \%$ & Average & $\mathbf{6 9 , 0} \%$ & $\mathbf{5 3 , 2 \%}$ & $\mathbf{2 7 , 0} \%$ \\
\hline
\end{tabular}

Source: Own illustration 
Concluding Schmid declared that the average internationality index of the DAX-enterprises was at $27 \%$, whereas the average share of foreign sales was at $69 \%$ and the average share of foreign employees was at $53 \%$. In that, Schmid arrives at similar conclusions as Lesch (2005) in the previous study which also shows that same discrepancy. Another result of Lesch that Schmid can confirm with his study is that the internationality of the management is reflected mainly by the international work experience, because a detailed examination of the internationality index leads to the following picture (Schmid 2007, pp. 5 et seqq.):

Table 8: Results of Schmid study (2007)

\begin{tabular}{|c|c|c|c|}
\hline \multicolumn{4}{|c|}{ Average of internationality index: $\mathbf{2 7} \%$} \\
\hline Multinational & International & International & International \\
members: $\mathbf{1 4} \%$ & education: $\mathbf{2 1} \%$ & Work experience: $\mathbf{4 6} \%$ & connections: 26 \% \\
\hline
\end{tabular}

Source: Own illustration

The illustration makes clear that the international work experience is the dominant indicator within the index. Therefore both studies arrive at the conclusion that the internationality of the executive board or supervisory board is reflected on average in the work experience of this group of people.

In the third study 80 enterprises from Sweden and Denmark were examined over the period of 9 years between 1990 and 1999 with regard to the foreign sales development and the share of international executive board/ management members. During the period of investigation the foreign sales increased from $43.15 \%$ to $60.11 \%$ and the share of international executive board members increased from $4.6 \%$ to $11 \%$ (Heijltjes et al. 2003, pp. 92 et seqq.). These data confirm the results of the above studies insofar as the internationality of the enterprise activities measured by foreign sales - is not reflected to a comparable extent in the internationality of the executive board members - measured by the share of international executive board members. However, it is correct that the share of international executive board members has more than doubled.

The fourth study examines the 150 largest transnational enterprises. Based on the results of Staples' previous study from 2007 which show a clear increase in the internationalization of the executive boards between 1993 and 2005 from $33.6 \%$ to $75 \%$ at the TNC (Staples 2008, pp. 31 et seqq.), Staples re-examined these facts in detail and detected that in his current survey in 103 out of 148 examined TNCs - that is in $69.6 \%$ of the enterprises at least one member of the executive board was not a native (Staples 2008, pp. 33-34). However, all in all the share of foreigners - measured by the 2147 examined executive board members - with 18,4\% is nevertheless small (Staples 2008, p. 35).

\subsection{Deductions from studies / literature}

Based on the above results the question arises, whether certain indicators of the behaviour dimension, e.g. the international work experience, have influence on the indicators of the performance and structure dimension. To this, the results of the first study of Lesch (2005) with regard to the indicators "international work experience in percentage" and "foreign sales in percentage" are analysed for possible correlations in relation to the DAX enterprises. As the sample size with $n=22$ enterprises is too low for an analytical consideration and only a possible trend should be revealed, thus the consideration is merely limited to a simple scatter diagram. This provides the picture in Figure 1.

Two trend lines can be read into the scatter diagram, which could be used as evidence that at least the foreign sales of the majority of the DAX enterprises correlate with the international work experience (see continuous trend straight line). The same applies to the foreign members of the executive board (see dotted trend straight line). However, above or respectively below the trend lines are diverse enterprises, which show a different behaviour. As these results do not provide any clear picture, the results of the second study by Schmid (2007) were also examined under the same perspective, but based on the given indicators. The illustration in Figure 2 puts exemplarily the percentage of the foreign sales in relation to the internationality index according to Schmid (2007) in percentage. 


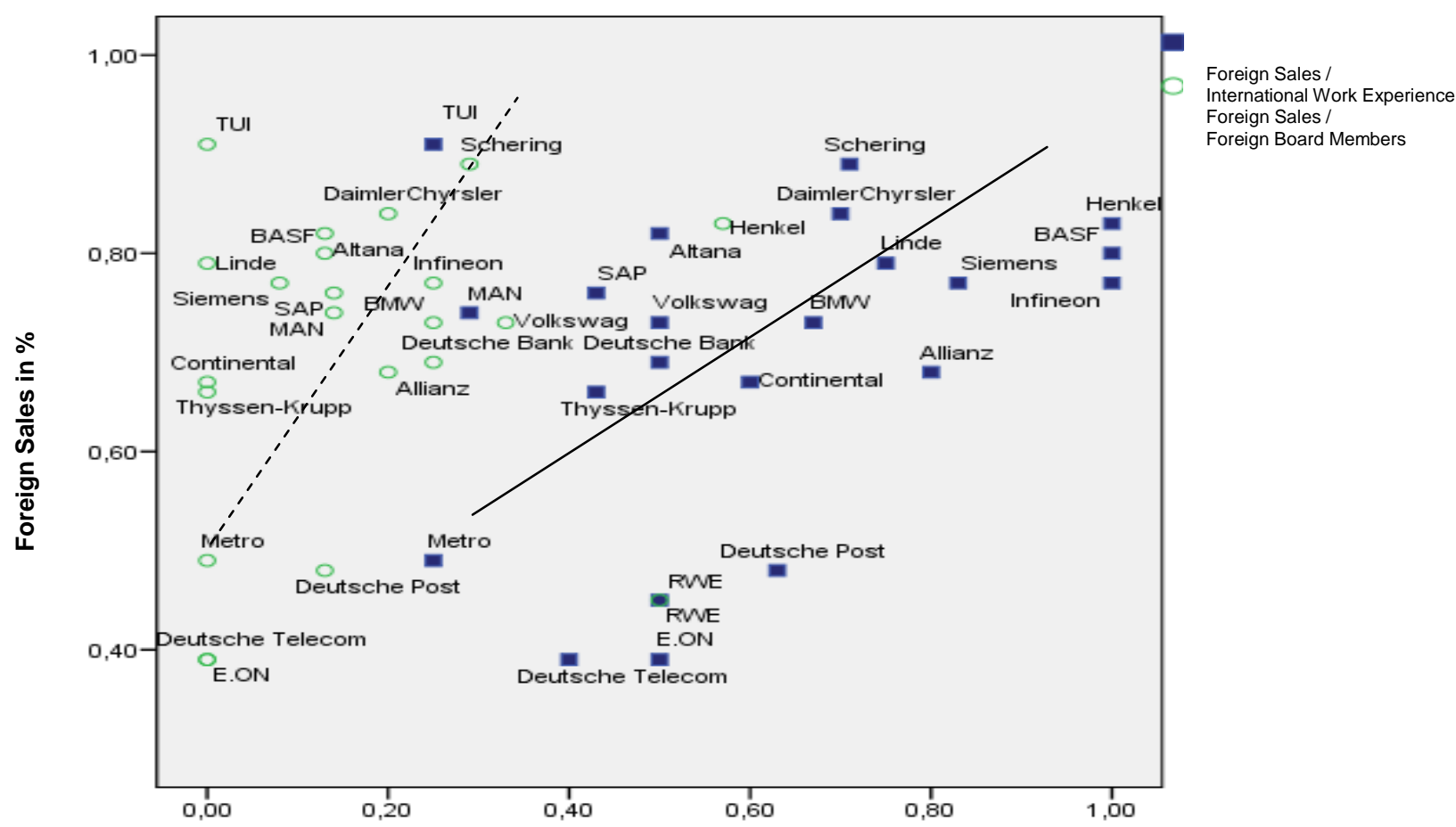

International Work Experience in \% /

Foreign Board Members in \%

Figure 1

Possible correlation between the foreign sales in \% on the one hand and the share of foreign board members in \% and their international work experience in \% on the other hand according to Lesch related to the DAX enterprises 2004 Source: Own illustration based on the data of Lesch (2005)

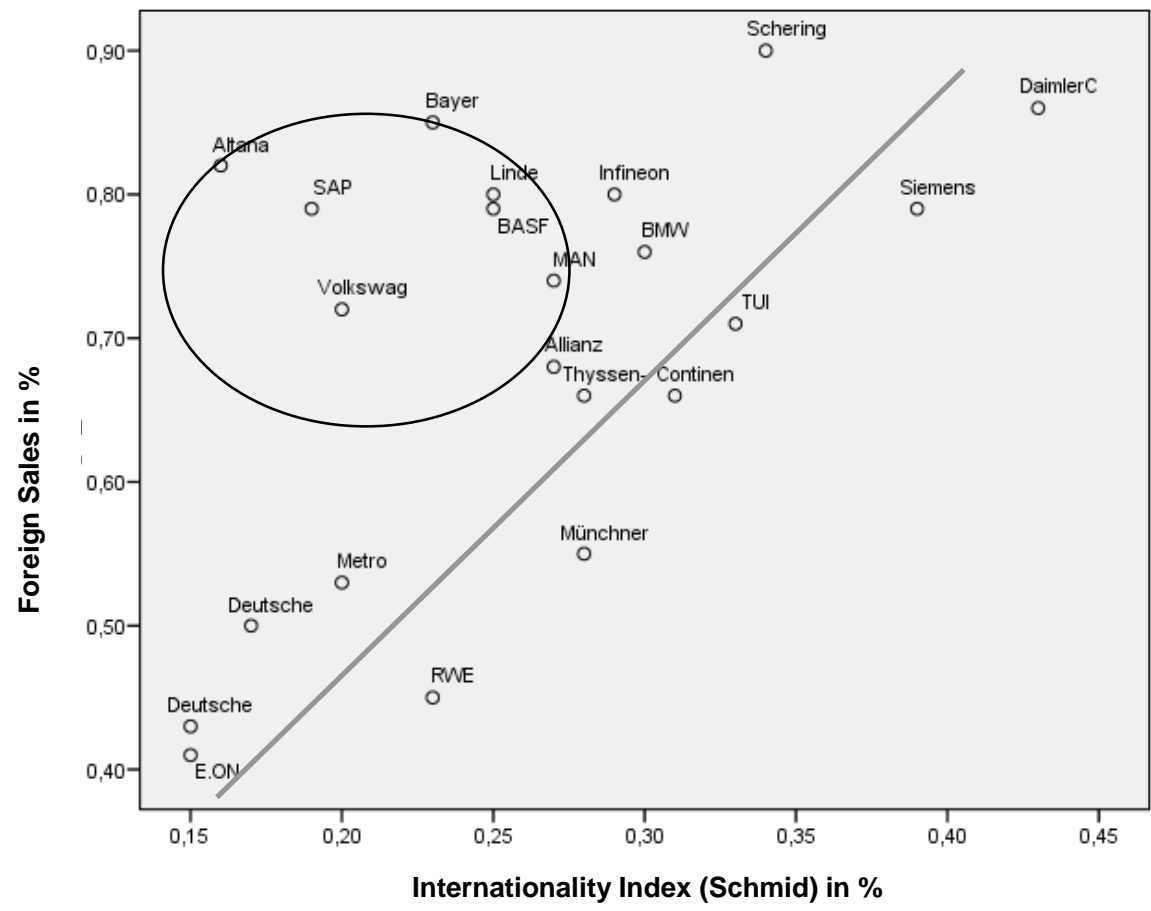

Figure 2

Possible correlation between the foreign sales in $\%$ and the internationality index in $\%$ according to Schmid with respect to the DAX enterprises in 2006

Source: Own illustration based on the data of Schmid (2007) 
From Figure 2 it can be seen that in comparison to the first study on a large part of the DAX enterprises, the relationship between increasing internationality index, including e.g. international work experience/education, and increasing foreign sales emerges more clearly (see trend straight line) such as with Metro, BMW or Siemens. However, there is again a group of enterprises (see circular area), which displays high foreign sales in spite of a low internationality index according to Schmid and thus deviates from the trend line.

The results of the third and fourth study as well confirm that the percentage of foreign members of the executive board as a possible scale for the internationality of the control committees is not mirrored by the scope of the enterprise's international activities, measured as share of foreign sales.

In summary, based on the above explanations the following insights are gained:

- The evaluations of the studies 1 and 2 prove that the internationality of the German executive boards/ managements differs considerably from the internationality of the enterprise activities.

- The internationality of the German executive boards is in both studies mainly determined by international professional experience/vocational training.

- The relationship between the foreign sales as a possible indicator for the performance dimension and the international professional experience/education - representing the behaviour dimension - can be assumed yet proven for the DAX enterprises.

As a derivation from the above results the question arises for the research, whether and if yes, how strong the influence of the internationality of the executive board on the internationality of the enterprise activities is. If this really applies, it would confirm several authors' opinion that higher internationality in the executive boards/supervisory boards may improve an enterprise's internationality (e.g. Schmid 2007, pp. 7 et seqq.).

\subsection{Research question and hypothesis formation}

Based on the considerations presented above different scientific questions arise, which are formulated as hypotheses as follows.

The general research question consists therein to check whether a measurable relationship exists between the internationality of the executive board and the internationality of the enterprise activities. All represented studies illustrate a more or less strong connection between the internationality of the members of the executive board and the foreign sales as the most important indicator of the internationality of the enterprise activities. Schmid uses in this connection an internationality index which consists of the indicators "multi-nationality, international professional experience, international education, and international connections (mandates)" (Schmid 2007, p. 5). Following hypotheses can be deduced from this:

H1: At SMEs there is a high correlation between the foreign sales as an indicator for the internationality of the enterprise activities on the one hand and international professional experience/vocational training of the executive board on the other hand.

H2: Only a low correlation exists between the foreign sales of SMEs on the one hand and the multi-nationality of the executive board and its international mandates on the other.

H3: The internationality of the chairmen of the executive board at SMEs has an above average influence on the internationality of the executive board as a whole and therewith on the internationality of the enterprise activities.

\section{SYSTEMATIC APPROACH}

For a review of the hypotheses, companies which are listed at the Singapore Stock Exchange are used, contrary to the studies mentioned above, where company data of large-scale enterprises were used (see: http://info.sgx.com). These are enterprises with a sales volume of up to 50 millions of euro and a maximum of 1,000 employees, which therefore - depending on definition - are classified as medium-sized business. This containment is based on the assumption that boards of directors in medium-sized businesses - in comparison to corporate boards - 
usually have a greater proximity to the operative business, which speaks for an easier feasibility of an international orientation of the executive board. The connection between the internationality of enterprises and the internationality of the executive boards should therefore - in comparison to the corporation - emerge on that assumption more clearly. The decision for enterprises from Singapore is based on the fact, that on the one hand the database in the form of annual reports for enterprises of this size was very good and on the other hand enterprises in Singapore were very early and intensively confronted with the globalisation, which increased considerably the probability for the existence of international enterprise activities relevant for this examination.

\subsection{Random sample}

The investigation is based on a sample of $n=100$ enterprises whose headquarters are in Singapore. From these enterprises the profile of 578 executive board members and 320 leading managers were examined for this investigation (Sommer 2007). The base was the annual reports of 2006, the Wright Reports, information gained from the home page of the concerned enterprises as well as a telephone survey (Sommer / $\mathrm{Ng} \mathrm{2006).}$

\subsection{Survey variables}

The indicators used by Schmid/Kretschmer were applied for measuring of the internationality of the executive board (Schmid/Kretschmer 2005, p. 10), since these also included the indicators introduced by the other three studies. The following table gives a summary:

Table 9: Indicators and their description

\begin{tabular}{|l|l|}
\hline \multicolumn{1}{|c|}{ Indicator identifier } & \multicolumn{1}{c|}{ Description } \\
\hline 1. Multinationality & $\begin{array}{l}\text { Percentage of executive board members with a divergent nationality (=with reference } \\
\text { to the corporate centre) in proportion to the total number of board members }\end{array}$ \\
\hline 2. International education & $\begin{array}{l}\text { Percentage of executive board members with an international education (= at least 2 } \\
\text { years) in proportion to the total number of board members }\end{array}$ \\
\hline $\begin{array}{l}\text { 3. International professional } \\
\text { experience }\end{array}$ & $\begin{array}{l}\text { Percentage of executive board members who spent working years abroad in } \\
\text { proportion to the total working years }\end{array}$ \\
\hline 4. International relation & $\begin{array}{l}\text { Percentage of executive board members with foreign mandates in proportion to the } \\
\text { total number of board members }\end{array}$ \\
\hline
\end{tabular}

Source: Own illustration

For measuring the internationality of the enterprise activities two indices were found out as an addition besides the central indicator "export sales" which was used in all examined studies: The TRANSNATIONALITY index and the TRANSNATIONAL ACTIVITY SPREAD INDEX.

\subsection{Analysis}

The analysis was carried out based on descriptive as well as analytical methods by use of the statistical software SPSS 15. In the first step the results were examined descriptively, in the second step an analytical evaluation was carried out including correlation analyses and multiple regressions.

\section{RESULTS}

\subsection{Descriptive part}

In the direct comparison to the examined DAX enterprises as classic large-scale enterprises (Schmid 2007, p. 5) essential deviations could be found out in the medium - sized enterprises from Singapore in terms of the internationality of the executive board, as the following table illustrates: 
Table 10: Comparative consideration between DAX enterprises and SES enterprises

\begin{tabular}{|l|c|c|}
\hline \multicolumn{1}{|c|}{ Indicators (average values) } & $\begin{array}{c}\text { DAX enterprise } \\
\text { from Germany } \\
\text { "Large enterprise" }\end{array}$ & $\begin{array}{c}\text { SES enterprise } \\
\text { from Singapore } \\
\text { "Medium sized } \\
\text { enterprises" }\end{array}$ \\
\hline A. Internationality of the executive board & & $13 \%$ \\
\hline Multinationality in percentage & $14 \%$ & $\mathbf{3 5 \%}$ \\
\hline International education in percentage & $21 \%$ & $18 \%$ \\
\hline International professional experience in percentage & $\mathbf{4 6 \%} \%$ & Not evaluated. \\
\hline International relation in percentage & $26 \%$ & $42 \%$ \\
\hline B. Internationality of enterprise activities & & $69 \%$ \\
\hline Foreign sales in percentage & $69 \%$ & \\
\hline
\end{tabular}

Legend: The indicator "international relations" has been excluded due to the insufficient number of enterprises having such mandates..

Source: Own illustration

While the results presented above strongly support Schmid's argumentation of the internationality of the executive board members being reflected by the professional experiences at DAX enterprises (Schmid 2007, pp. 5 et seqq.), it turned out that in contrast to this, in SES enterprises the international education can be seen as the decisive factor. About 35\% of the members of the executive board have an international education of more than two years, mainly in Great Britain and the USA (Bachelor / Master, in a few cases PhD). The relevance of international education is almost mirrored by the share of foreign sales in proportion to total turnover.

\subsection{Analytical part}

In the context of the analytical examination the product moment correlation according to Pearson was used, since it is the description of the relation between interval scaled and normally distributed variables (Zöfel 2003, pp. 149 et seqq.). In the first step it was checked, whether the percentage details presented in the descriptive part on the individual internationality indicators of the executive board can be linked to the internationality of the enterprise activities of the enterprises from Singapore. The latter is here represented by the share of the companies' foreign sales. Carrying out this analysis the following picture emerges:

Table 11: Product-moment correlation between the internationality indicators and share of foreign sales

Correlations

\begin{tabular}{|c|c|c|c|c|c|}
\hline & & $\begin{array}{c}\text { Multinationalit } \\
\text { y_per_cent }\end{array}$ & $\begin{array}{c}\text { International_ } \\
\text { Education_- } \\
\text { per_cent }\end{array}$ & $\begin{array}{l}\text { International_ } \\
\text { Work_- } \\
\text { Experience_- } \\
\text { per_cent }\end{array}$ & $\begin{array}{l}\text { Foreign__ } \\
\text { Sales_per_ } \\
\text { cent }\end{array}$ \\
\hline \multirow[t]{3}{*}{ Multinationality_per_cent } & Pearson Correlation & 1 & $.407^{* t}$ & $.402^{\text {th }}$ & $.257^{\text {th }}$ \\
\hline & Sig. (2-tailed) & &, 000 &, 000 & ,010 \\
\hline & $N$ & 100 & 100 & 100 & 100 \\
\hline \multirow{3}{*}{$\begin{array}{l}\text { International_Education__ } \\
\text { per_cent }\end{array}$} & Pearson Correlation & $.407^{* 1}$ & 1 & .183 & .126 \\
\hline & Sig. (2-tailed) &, 000 & & ,068 & .212 \\
\hline & $N$ & 100 & 100 & 100 & 100 \\
\hline \multirow{3}{*}{$\begin{array}{l}\text { International_Work } \\
\text { Experience_per_cent }\end{array}$} & Pearson Correlation & $.402^{*}$ & .183 & 1 & $677^{t+1}$ \\
\hline & Sig. (2-tailed) &, 000 & .068 & &, 000 \\
\hline & $\mathrm{N}$ & 100 & 100 & 100 & 100 \\
\hline \multirow[t]{3}{*}{ Foreign_Sales_per_cent } & Pearson Correlation & $.257^{\text {\#x }}$ & .126 & $.677^{\star 1}$ & 1 \\
\hline & Sig. (2-tailed) & ,010 & .212 & ,000 & \\
\hline & $\mathrm{N}$ & 100 & 100 & 100 & 100 \\
\hline
\end{tabular}

". Correlation is significant at the 0.01 level (2-tailed).

Source: Own illustration - SPSS 15

Hereafter is $r=0.677$ a middle or high correlation between the foreign sales and the international work experience with a significance level of $p<0.01$. Furthermore it could be noticed that the multi-nationality correlates 
only little $(r=0.257)$ with the foreign sales, however this is also very significant. In contrast to this, there obviously consists only a very low correlation of $r=0.126$ between the foreign sales and the international education, which is not significant. As the correlation calculation checks only the intensity of the connection of two variables, the analysis of a regression is also considered to check whether there is a formulistic relationship. The application of multiple regression seems advisable here, as the dependent variable "foreign sales" depends on a multitude of independent variables.

In the context of this examination only the three variables connected to the internationality of the executive board, "multi-nationality, international professional experience and education", shall be analysed out of the variety of possible independent variables. The application requirements for the multiple regression are fulfilled in this context, as it concerns the interval scaled and normally distributed database. The sample size with $\mathrm{n}=100$ is in this relation suitable since a clear decision on the validity of the alternative hypothesis and null hypothesis was guaranteed at given $\alpha$ - and $\beta$ - fault (Bortz 2005, p. 125). Backhaus recommends generally for parameter estimation $n$ $=100$ (Backhaus et al 2005, p. 370). An in empirical research very popular variant of stepwise regression was used. (Backhaus et al 2005, pp. 105 et seqq.; Sachs 1999, p. 225), which yielded the following results:

Table 12: Multiple regression of the internationality indicators on share of foreign sales

Coefficients ${ }^{a}$

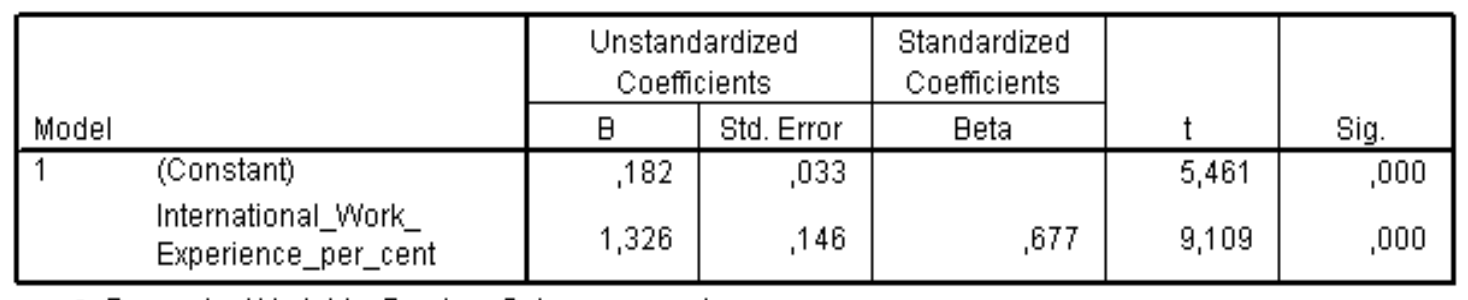

a. Dependent Variable: Foreign_Sales_per_cent

Source: Own illustration - SPSS 15

After this, only the variable "international professional experience" is again significant. The two others were excluded from the model. With a determination coefficient of $\mathrm{R}^{2}=0.458,45.8 \%$ of the variation of the foreign sales are explained. With an empirical $\mathrm{F}$ value of 82.972 this is considerably above the theoretically demanded $\mathrm{F}$ value of 2.75 (Backhaus et al 2005, p. 809). Thus, the postulated relationship can be assumed to be significant.

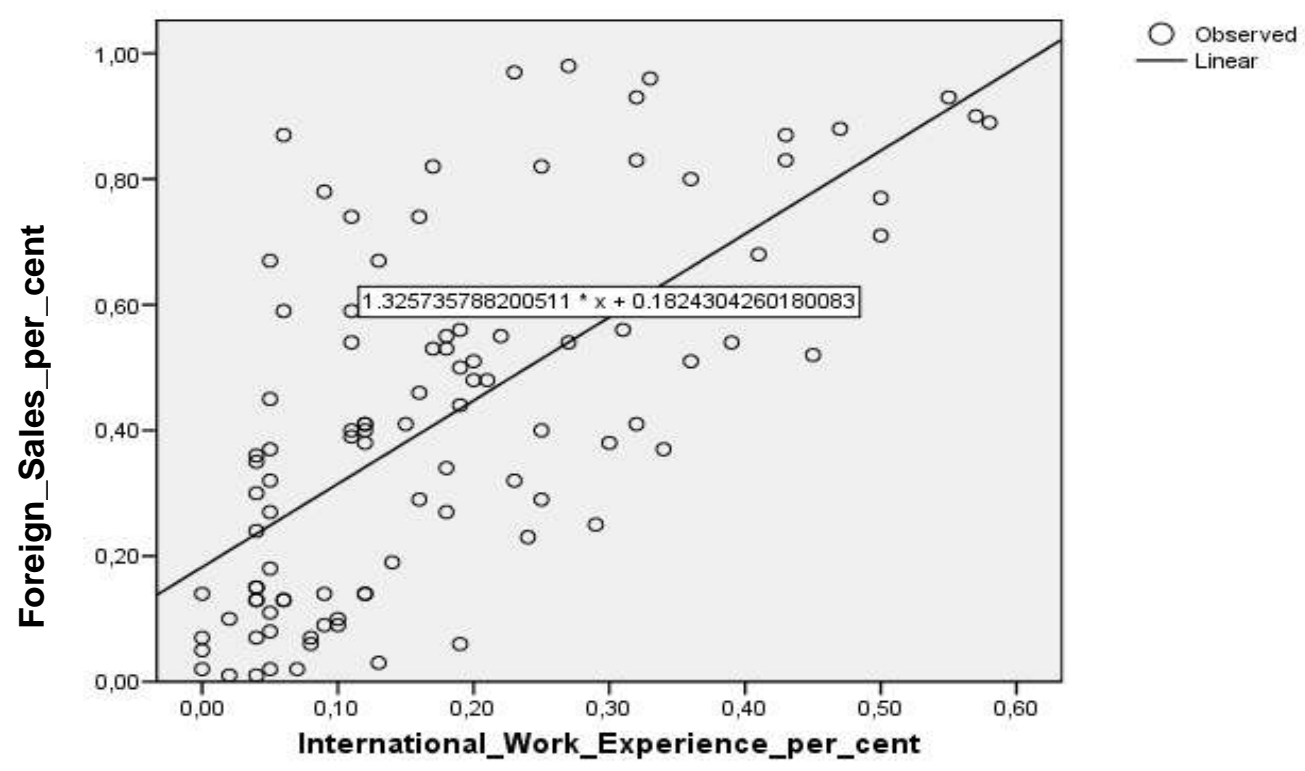

Figure 3: Regression line based on the multiple regression of the internationality indicators on share of foreign sales Source: Own illustration- SPSS 15 
The graph shows that a linear relationship between foreign sales and international professional experience can be identified being highly significant. This is largely in the harmony with the descriptive results from the studies of Lesch (2005) and Schmid (2007). To stabilize the above results the indicator "foreign sales" was replaced by the Transnationality Index (TNI) which is used by UNCTAD. Here the correlation is also confirmed between the TNI as a substitute for the export sales and the internationality indicators of the executive board on a slightly higher level with $r=0.745$, which also was very significant.

Due to the surprisingly low correlation between the international education and the internationality of the enterprise activities another correlation was carried out. The objective was to examine, whether the international education of long standing members of the executive boards, members of the executive board with a high share amount, long-standing chairman or members of the executive board considerably correlate with the share of foreign sales or the TNI. However the results show that this was not the case. The following correlations were obtained:

Table 13

Product-moment correlation between the international education of the chairman of the executive board and the international education of the members of the executive board per capita

Correlations

\begin{tabular}{|c|c|c|c|}
\hline & & $\begin{array}{c}\text { International_ } \\
\text { Education_- } \\
\text { per_capita }\end{array}$ & $\begin{array}{l}\text { International_ } \\
\text { Education_- } \\
\text { chairman }\end{array}$ \\
\hline $\begin{array}{l}\text { International_Education_ } \\
\text { per_capita }\end{array}$ & $\begin{array}{l}\text { Pearson Correlation } \\
\text { Sig. (2-tailed) } \\
N\end{array}$ & $\begin{array}{r}1 \\
100\end{array}$ & $\begin{array}{c}, 619^{*} \\
, 000 \\
100\end{array}$ \\
\hline $\begin{array}{l}\text { International_Education_ } \\
\text { chairman }\end{array}$ & $\begin{array}{l}\text { Pearson Correlation } \\
\text { Sig. (2-tailed) } \\
N\end{array}$ & $\begin{array}{c}619 * 1 \\
, 000 \\
100\end{array}$ & $\begin{array}{r}1 \\
100\end{array}$ \\
\hline
\end{tabular}

Thereafter, the international education of the chairman of the executive board shows a medium or even high-level, significant correlation of $r=0.619$ with the extent of the international education of the other members of the executive board.

\section{Discussion and conclusion}

\subsection{Hypothesis examination}

The results can be interpreted with regard to the formulated hypotheses as follows:

Hypothesis 1: This can partly be confirmed as there is a moderate to a high correlation between the foreign sales and the international professional experience. With regard to the international education there is only a very low correlation. Thus, international professional experience seems to play an important role in explaining the scope of an enterprise's international activities. These results further illustrate clearly that although the internationality of the executive boards of SMEs in Singapore is characterized by a higher international level of training in comparison to the DAX enterprises, the latter does not necessarily affect the international enterprise activities. Furthermore it can be noted in the margin that apparently the orientation towards certain markets is not necessarily influenced by the choice of the education location, because although an education of the majority of the executive board members has taken place in Great Britain and the USA, the focus of today's foreign activities - measured in terms of the export sales - is strongly narrowed to the Asian region. This can also be seen in another indicator, the overseas branches. Approx. 87\% of the overseas branches of the examined SMEs are located in the Asian region.

Hypothesis 2: The expected low correlation between the multi-nationality and the share of foreign sales could be confirmed. In this connection, it can be assumed that the increasing percentage of the foreign members improves formally - measured in percentage figures - the internationality of the executive board, but does not have necessarily 
an effect on the internationality of the enterprise activities. The multiple regression analysis carried out on this reveals that only international work experience as one of the three independent variables turned out to be statistically relevant with respect to the dependent variable share of foreign sales. The survey and inclusion of the international mandates of the executive board were renounced, since on the one hand these were rare in the case of SMEs, on the other hand the database was afflicted with considerable uncertainties.

Hypothesis 3: The last hypothesis referred to the question, to what extent the chairman of the executive board, often the founder of the company with a corresponding majority shareholding and longer enterprise membership, has a special influence in SMEs on the internationality of the enterprise activities. Interestingly, no significant relationship between the internationality of the chairman of the executive board and the share of foreign sales could be identified. The attempt to find an influence by including weights based on shares and membership, respectively, also remained unsuccessful. However it could be proved that the internationality of the chairman regarding his international education influenced the per capita internationality of the general management in terms of education. In simple words: Internationally oriented executive boards are looking for international oriented executive board colleagues.

\subsection{Random sampling quality and generalization}

The sample of $\mathrm{n}=100$ enterprises does not claim representativeness for the medium-sized businesses in Singapore, but contains an essential percentage of the listed SMEs.

\subsection{Summarized review}

It was claimed that the 'international professional experience' is one out of four indicators of the internationality of the executive board according to Schmid (2007), which is - expressed in percent - of outstanding importance compared to the other indicators (Schmid 2007, p. 5) and on the other hand has a relevant influence on the internationality of the enterprise activities. The first statement could not be confirmed for the enterprises in Singapore. Seen as a percentage, the outstanding indicator for the internationality of the executive board was the high degree of an international education. This may be due to Singapore's specific situation in terms of country size, colonial heritage, close relationships with UK, and others. The second statement that the international professional experience has the greatest influence of the four indicators on the internationality of the enterprise activities measured as share of export sales could be confirmed. These findings clearly say that an indicator's value must not be confused with its explanatory power on the company's degree of internationalization. Another result supports this suggestion. International professional experience scored relatively low for board internationality of Medium-sized companies from Singapore but turned out to have a large impact on an enterprise's degree of internationalization. Summarizing these considerations, it can be stated that pure descriptive data describing the influence of indicators on board internationality are not pivotal to explaining company internationality. Only applying analytical methods to the data revealed the strong relationship between professional experience abroad and the share of foreign sales. In other words: a high percent value for a certain indicator does not mean that it has a large influence on company internationality. As an example, in the Singapore sample, international education had a value of $35 \%$ but showed no significant impact on the share of foreign sales.

This aspect is especially relevant as Schmid (2007, p.4) himself states that for his sample there is a discrepancy between board internationality and company internationality - the second one is higher than the other. Therefore it remains rather unclear which impact indicators have on the company's degree of internationalization. If one is interested in how the company's internationality can be improved, the impact of indicators on board internationality may provide only first insights, i.e. for a more comprehensive analysis a closer look on how indicators do not only influence board internationality but in particular company internationality is indispensable. This was done in the paper at hand.

\subsection{Practical relevance and future work}

The results can be interpreted in such a way that for companies intending to increase their international orientation a corresponding internationally oriented executive board is highly recommended. On the other hand this goal is not achieved necessarily by appointing people from abroad to the executive board or members having an international education. Rather, when looking for future members of the board, great attention should be paid to people having made an appropriate professional experience abroad. In addition, suitable combinations of the 
qualifications make particularly sense. For the German medium-sized enterprises with a currently rather lower internationality in the executive board or management in comparison with Singapore this means the search for internationally experienced managers on the meanwhile highly competitive job market. Alternatively or in addition, intensifying specific further development of the companies' high potentials with first international experiences is strongly recommended. The results further suggest that recruiting managers primarily based on the multi-nationality criterion does not contribute to achieving the goal. In other words, future studies should deal with whether the multinationality who was by several scholars claimed to be an important indicator for the internationality of an executive board has been overrated in the past. With reference to assessing the internationality of an executive board, it has to be investigated whether the conceptualization could be extended by including weights for each indicator based on corresponding correlation or regression coefficients. As an example, Schmid's (2007) approach which proposes equal weights for each indicator shows as presented above room for improvements and may benefit from such extension.

\section{ACKNOWLEDGEMENTS}

The author would like to express his gratitude to the International Lake Constance University / Interreg IIIA for supporting this research by funding the corresponding research project SARI-S (SMEs' Awareness of the Relevance of Internationalization -Status Quo), project no. \#513/06.

\section{AUTHOR INFORMATION}

Lutz Sommer is Professor at Albstadt-Sigmaringen University in the Department of Business Administration and Engineering. He studied in Germany (Berlin Institute of Technology / University of Hagen ) and Poland ( University of Gdansk ) and holds a BEng / MEng in Engineering and a BSc / MSc in Business Administration and Engineering as well a $\mathrm{PhD}$ in economics.

His research activities deal with the internationalization activities of Small and Medium-Sized Enterprises (SME). In particular, the focus is on the influence of socio-psychological factors on the owner-managers' decision making processes in terms of internationalization.

\section{BIBLIOGRAPHY}

1. Aharoni, Y. (1971): On the definition of a multinational corporation. In: The Quarterly Review of Economics and Business, Vol. 11, No. 3, pp. 27 - 37

2. Ajzen, I./Fishbein, M. (1980): Understanding Attitudes and Predicting Social Behaviour; Englewood Cliffs

3. Ajzen, I./Madden, T.J. (1986): Prediction of goal-directed behaviour; in: Attitudes, intentions and perceived behavioural control; in: Journal of Experimental Social Psychology, Vol. 22, No. 5, pp. 453-474

4. Allport, G.W. (1935): Attitudes; in: Carl Murchison (Ed.): A Handbook of Social Psychology, pp. 798-844, Worcester

5. Backhaus, K./Erichson, B./Plinke, W./Weiber, R. (2005). Multivariate Analysemethoden. Eine anwendungsorientierte Einführung, 11th ed., Berlin

6. Bartlett, C.A./Goshal, S. (1989): Managing across borders. The transnational solution, 2nd ed., Boston

7. Berghe, D.A.F. (2003): Working across borders - Multinational enterprises and the internationalization of employment, Rotterdam

8. Bortz, J. (2005): Statistik für Human- und Sozialwissenschaftler, 6th ed., Berlin

9. Bruck, N.K./Lees, F.A. (1966): Foreign content of U.S. corporate activities; In: Financial Analyst Journal, Vol 22, No. 5, pp. 127 - 132

10. CEDEFOP (2002): Internationalisation and changing skills needs in European small firms (Internationalisierung und der veränderte Qualifikationsbedarf in europäischen kleinen Unternehmen) Synthesis Report: CEDEFOP Reference Series 23 and Country Report Greece; European Centre for the Development of Vocational Training; Luxemburg

11. Cheng, J.L./Ramaswamy, K. (1989): Towards a systems typology of multinational corporations. Some conceptual and research implications; In: Academy of Management, Vol. 46, p. 106 - 110

12. Claver, E./Quer, D. (2001): Early steps to becoming a multinational. How do small firms go multinational? In: Journal of General Management, Vol. 27, No. 2, pp. 17 - 34 
13. Dörrenbächer, C. (2000): Measuring corporate internationalisation. A review of measurement concepts and their use. In: Intereconomics, Vol. 35, No. 3, pp. 119-126.

14. DP Information Group (2007): A time for local SMEs to look back at fundamentals; Singapore www.dpgroup.sg

15. Fischer, L.D. (2006): Internationalität der Unternehmung - Aktueller Forschungsstand, Analyse und Konzeptualisierung; Dissertation 2006, Otto-Friedrich-Universität Bamberg - Germany

16. Flash Eurobarometer 196 (2007): Beobachtungsnetz der europäischen Union, pp. 6 et seqq.; The Gallup Organization

17. Germann, H./Rürup, B./Setzer, M. (1996): Globalisierung der Wirtschaft - Begriff, Bereiche, Indikatoren. In: Steger, Ulrich (Ed.): Globalisierung der Wirtschaft. Konsequenzen für Arbeit, Technik und Umwelt Berlin, Heidelberg, New York, pp. 18 - 56

18. Hassel, A./Höpner, M./Kurdelbusch, A./Rehder, B./Zugehör, R. (2003): Two dimensions of the internationalization of firms. In: Journal of Management Studies, Vol. 40, No. 3, p. 705 - 723

19. Hederer, G./Kumar, B.N./Müller-Heumann, G. (1970): Begriff und Wesensinhalt der internationalen Unternehmung. In: Betriebswirtschaftliche Forschung und Praxis, Vol. 22, pp. 509 - 521

20. Heijltjes, M./Olie, R./Glunk, U. (2003): Internationalization of top management teams in Europe. In: European Management Journal , Vol. 21, No. 1, pp. 89 - 97

21. Heinrich, A. (2003): Globale Einflüsse und die Corporate Governance des russischen Erdöl- und Erdgassektor. Forschungsstelle Osteuropa, Working paper No. 46, Bremen

22. Hommel, U./Brockmann, M. (2007): Aktive Globalisierung - Chancen für deutsche Familienunternehmen?; Oestrich-Winkel

23. Hughes, J.S./Logue, D.E./Sweeney, R.J. (1975): Corporate international diversification and market assigned measures of risk and diversification. In: Journal of Financial and Quantitative Analysis, Vol. 10, No. 4, pp. 627 - 637

24. Ietto-Gillies, G. (1998): Different conceptual frameworks for the assessment of the degree of internationalization. An empirical analysis of various indices for the top 100 transnational corporations, In: Transnational Corporations, Vol 1, No. 7, pp. 17 - 39

25. Johanson, J./Gunnar-Mattsson, L. (1986): International marketing and internationalization processes. A network approach, In: Turnbull, P.W./Paliwoda, S.J. (Eds.): Research in international marketing. London, Sydney, Dover et al., pp. 234 - 265

26. Kutschker, M./Schmid, S. (2006): Internationales Management; 5th ed., Munich, Vienna

27. Lesch, C. (2005): Internationale Lenker, nationale Kontrolleure - Eine Untersuchung der Internationalität von Vorstand und Aufsichtsrat der DAX-Unternehmen, Consultancy SIMON-KUCHER \& PARNTER, Bonn

28. Max-Planck-Institut für Gesellschaftsforschung (2002): Wandel durch Internationalisierung, Cologne

29. Mittelstandsbarometer (2007): Den Aufschwung festigen - Beschäftigung und Investitionen weiter vorantreiben. Mittelstandsmonitor 2007 - Jährlicher Bericht zu Konjunktur- und Strukturfragen kleiner und mittlerer Unternehmen, Frankfurt am Main

30. Observatory of European SMEs (2003): Report No. 4 - Internationalisation of SMEs; Luxemburg

31. Perlmutter, H.V. (1969): The tortuous evolution of the multinational corporation; A drama in three acts. In: Columbia Journal of World Business, Vol. 4, No. 1, pp. 9 - 19

32. Perridon, L./Rössler, M. (1980): Die internationale Unternehmung. Entwicklung und Wesen. In: WiSt, Vol. 9, No. 5, pp. 211-217

33. Raghunathan, S.P./Chandran, R. (1990): Globality: Dimensions, Qualifiation, and Measurement; In:. Academy of International Business Proceedings, Toronto. 1990, p 1-2.

34. Rosenberg, M.J./Hovland, C.I. (1960): Cognitive, affective, and behavioral components of attitude; in: Rosenberg, M.J./Hovland; C.I./McGuire, W.J./Abelson, R.P./Brehm, J.W. (eds.): Attitude Organization and Change: An Analysis of Consistency among Attitude Components; New Haven, pp. 1-14

35. Sachs, L. (1999): Angewandte Statistik - Anwendung statistischer Methoden; 9th ed.; Berlin

36. Schmid, S. (1996): Multikulturalität in der internationalen Unternehmung. Konzepte, Reflexionen, Implikationen. Wiesbaden

37. Schmid, S. (2007): Wie international sind Vorstände und Aufsichtsräte? - ESCP-EAP Working Paper Nr. 26, Sept. 2007, Berlin

38. Schmid, S./Kretschmer, K. (2005): How International are German Supervisory Boards? - An Exploratory Study, ESCP-EAP Berlin 
39. Sommer, L./Ng, C. (2006): Internationalization of SME; unpublished working paper - AlbstadtSigmaringen University

40. Sommer, L./Durst, S./Haug, M. (2007): The role of the international Owner-Manager Identity in the Internationalization Process of SME; The Business Review, Cambridge - Vol. 9, No. 1, pp. 256 - 266

41. Sommer, L. (2007): Board Internationalization Index - Characteristics of SME; to be published in the near future

42. Staples, C. (2008): Cross-Border Acquisitions and Board Globalization in the World's largest TNCS 1995 to 2005, The Sociological Quarterly, Vol. 49, No. 1, pp. 31 - 51

43. Sullivan, D. (1994): The "Threshold of Internationalization". Replication, extension, and reinterpretation, In: Management International Review, Vol. 34, No. 2, pp. 165 - 186

44. Sullivan, D. (1996): Measuring the degree of internationalization of a firm. A reply, In: Journal of International Business Studies, Vol. 27, No. 1, pp. 179 - 192

45. UNCTAD (1995): World investment report - 1995. Transnational corporations and competitiveness, New York, Geneva

46. Zöfel, P. (2003): Statistik für Psychologen im Klartext, Munich

\section{NOTES}


NOTES 